\section{酸成分アミノ酸, アミン成分アミノ酸}

通常, アミノ酸とアミノ酸, ペプチドとアミノ酸, ペ プチドとペプチドを縮合させてペプチド形成反応を行う 場合, 一方の基質のアミノ基と, 他方の基質のカルボキ シル基をそれぞれ保護しておく必要がある。従って, ア ミノ基あるいはイミノ基を保護基で保護し，カルボキシ ル基のみに反応点がある $\mathrm{N}$-保護アミノ酸(または $\mathrm{N}$-保 護ペプチド)を酸あるいはC-成分アミノ酸(または酸成 分ペプチド)といい, 逆にカルボキシル基をエステル化, あるいはアミド化してアミノ基またはイミノ基のみに反 応点のあるアミノ酸エステルあるいはアミノ酸アミド類 (またはぺプチド類)をアミンあるいは N-成分アミノ酸 (またはアミン成分ペプチド)と称する。

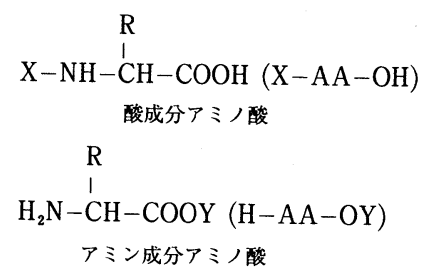

（米沢養躬）

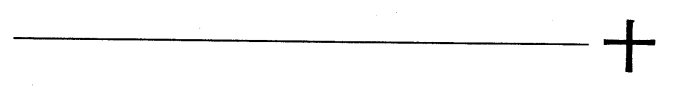

\section{Swern 酸化}

ジメチルスルホキシド(DMSO) を酸無水物, 酸クロリ ド,カルボジイミドなどの求電子剤によっで活性化”さ せた後, 1 級あるいは 2 級アルコールを加えアルコキシ スルホニウム塩とし, 同一容器中でトリエチルアミンな どの第 3 級アミンと処理しイリドの形成とつづく分子内 脱離反応を起こさせて対応するアルデヒドあるいはケト ンを得る手法は Pfitzner-Moffat 酸化として良く知られ ている。Swern らは求電子骭としてオキザリルクロリド が，(1)極めて緩和な条件(低温)で DMSO を活性化する, (2)好ましくない副生物および副反応物をもたらさない, 従って(3)処理しやすく好収率をもたらす，という特徵を 示すことを見出し, 以来本条件下の酸化反応は Swern 酸化と呼ばれ多用されている(レビュー：A.J. Mancuso, D. Swern, Synthesis, 1981, 165)。

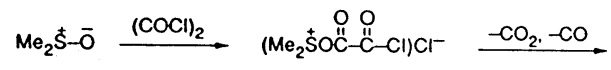

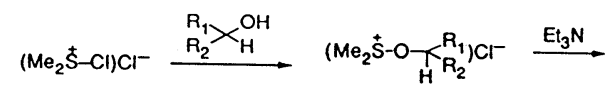

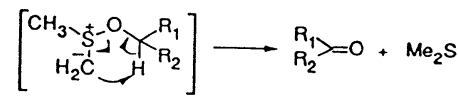

(小笠原國郎)

\section{CTH 法}

アミノ酸などのアミノ基やカルボキシル基の保護基と してそれぞれベンジルオキシカルボニル $(Z)$ 基やベンジ ル基がしばしば用いられる。これらの保護基は接触還元 などによって除去する方法が広く知られている。 Catalytic Transfer Hydrogenation (CTH) 法は通常の還元 (接 触水素化分解) とは異なり, 水素化合物と触媒との共存 下で水素を直接基質に転移させて還元する方法である。

例えば, $Z$-ペプチドのメタノール溶媒中に $10 \%$ パラ ジウム炭素存在下, ギ酸アンモニウムを加えて常温常圧 で 5 10 分間放置するだけで定量的に $Z$ 基が除去でき る。ベンジルエステルやベンジルエーテル類についても 同様に水素化分解が可能であり, 通常の接触還元が数時 間要するのに比べ著しく早い反応である。特に, ペプチ ド鎖中に二重結合を有するデヒドロペプチドについては 二重結合への水素添加より先に $Z$ 基が除去できるため 同種のペプチドへの利用にも有用である。

（米沢養躬）

$$
\text { シラトラン }
$$

右の構造を持つ中性の 5 配位ケイ素化合物をシラトラ ンと通称する。ケイ素のかわりにホウ素, ゲルマニウムなどが入ったものは各々ボ ラトラン, ゲルマトランなどという。シ ラトラン ( $\mathrm{X}=\mathrm{Ph}$ の場合) では窒素の弧 立電子対がケイ素に分子内配位した三角<smiles>[X][Si]123(OCCN1CCO)OCCN2CCO3</smiles>
両錐構造をもつことが, X 線結晶解析により明らかにさ れている。

シラトランはナトリウムエトキシドなどの塩基存在 下, トリエタノールアミンとトリアルコキシシランのア ルコキシ交換反応によって容易に合成できる。生理活性 を示すケイ素化合物はそれほど多くは知られていない が, アリールシラトラン誘導体 $(\mathrm{X}=\mathrm{Ar})$ は著しい毒性を 示し, フェニルシラトランはストリキニーネの数倍に及 ぶ強い毒性 $(\mathrm{LD}=0.33$, 白マウス $)$ を示す。また, 種特 異性があり, 温血動物とくに噄菊類に強い活性を示すこ ともその特徵の一つである。Voronkov を中心に本化合 物の薬理活性に関する研究はこれまで多数ある。 (M.G. Voronkov, Topics in Current Chem., 84, 77 (1979); 熊田 誠, 化学, 28, 213 (1973)を参照) (細見 彰) 